\title{
Sintering Behavior of Ash from Combustion of Jincheng Coal and Pine Sawdust Blends
}

\author{
Nijie Jing, ${ }^{\mathrm{a}, *}$ Qinhui Wang, ${ }^{\mathrm{b}}$ Hongmei Zhu, ${ }^{\mathrm{a}}$ Yan Liu, ${ }^{\mathrm{c}}$ and Long Han ${ }^{\mathrm{d}, *}$
}

\begin{abstract}
Sintering behaviour of ash specimens from blends of Jincheng (JC) coal and pine sawdust (PS) was investigated using a pressure-drop sintering device combined with scanning electron microscopy-energy dispersive spectroscopy (SEM-EDS), X-ray diffraction (XRD) analysis, and FactSage modeling. The sintering temperatures consistently displayed a decreased trend when the PS was added into JC. In addition, the ashing temperature had an important influence on the sintering temperature of ash. The SEM analysis revealed a fine, irregular, and fibrous texture in the ash specimens from the lower ashing temperature. Regular block-shape particles were present in the ash from the higher ashing temperature. The EDS results showed that more $\mathrm{Ca}$ and $\mathrm{Fe}$ appeared with the increase of ashing temperature and more $\mathrm{K}$ and $\mathrm{Na}$ appeared, while $\mathrm{Ca}$ and Fe decreased with the addition of PS. The XRD analysis revealed that low-temperature minerals melted or co-fused with $10 \%$ PS addition into coal, while the hightemperature minerals formed with increased ashing temperature. The FactSage calculation indicated that the alkali and alkali earth metal species mainly existed in the forms of aluminosilicates and silicates. Calcium, magnesium, and potassium played a vital role during the sintering of the blends with PS.
\end{abstract}

Keywords: Sintering; Biomass; Coal; Co-firing

Contact information: a: Institute of Energy Utilization and Automation, Hangzhou Dianzi University, Hangzhou, Zhejiang, China; b: State Key Laboratory of Clean Energy Utilization, Zhejiang University, Hangzhou, Zhejiang, China; c: Institute of Energy, Hangzhou Dianzi University, Hangzhou, Zhejiang, China; d: Institute of Energy and Power Engineering, College of Mechanical Engineering, Zhejiang University of Technology, Hangzhou, Zhejiang, China;

*Corresponding authors: njjing@hdu.edu.cn; LongHan@zjut.edu.cn

\section{INTRODUCTION}

Biomass, as a zero-emission renewable resource, has competitive advantages of high reaction activity and low pollutant emission (Wei et al. 2017; Xiong et al. 2018). The co-firing of coal with biomass is a promising method for reducing net $\mathrm{CO}_{2}, \mathrm{SO}_{x}$, and $\mathrm{NO}_{x}$ emissions from existing coal-fired power plants, as well as one of the most cost-effective technologies to use renewable materials on a large scale (Rizvi et al. 2015; Vuthaluru et al. 2015; Priyanto et al. 2016; Zhou et al. 2018). However, there are new challenges and problems due to the high content of alkali metals in biomass. The differences of biomass and coal in the characteristics and a series of complex physical and chemical changes occurring during the co-firing will lead to new problems related to ash, even more serious than those encountered during single coal combustion (Sami et al. 2001; Zhou and Ma 2017). Therefore, it is necessary to study the related characteristics of the ash during the co-firing of coal and biomass. 
Ash sintering is a key early step in the processes of ash fouling and slagging in coalfired utility boilers (Li et al. 2016). Sintering can result in some severe ash-related problems, such as deposition and fouling on the heat transfer surfaces. Agglomeration, clogging, and blockage are experienced due to sintering at the lower temperature regime (Selvakumaran et al. 2014). Many researchers have studied the properties of co-firing of coal and biomass, ash deposition, and slagging (Teixeira et al. 2012; Chen et al. 2015; Kulazynski et al. 2018; Lu et al. 2018; Zhu et al. 2018). Sajdak et al. (2019) investigated the impact of biomass chemical composition on the characteristic ash melting behavior of a biomass/coal blend made for use in the co-firing of power plants. Zhou et al. (2019) investigated the effects of two biomass ashes (corn stalk (CS) and wood pellet (WP)) on the sintering behaviors of two types of coal (high melting Shanxi coal (SX) and low melting Shenhua coal $(\mathrm{SH})$ ). The results showed that $\mathrm{CS}$ ash promoted $\mathrm{SH}$ ash sintering by accelerating the formation of diopside and amorphous minerals, and calcium played a vital role during the sintering of high blend ratio of WP. Xing et al. (2019) predicted the effects of a different combination of biomass and coal on the inorganic phase changes. The FactSage model predicted some inorganic phases that were not detected in the XRD, particularly in low temperature ashes, and predicted the beginning of slag formation below the initial deformation temperature. Zhang and Zhou (2019) found that alkalis and Fe compounds strongly affected the adhesion behavior. Nickel coating had a positive effect on controlling the slagging deposit through altering the content of alkalis and $\mathrm{Fe}$ compounds during co-firing of coal and biomass. However, studies of the effect of biomass types on sintering of coal ash are still scarce. The problem of slagging remains far from being solved. Moreover, the effect of combustion parameter and blends ratios on the ash behavior is still unclear.

This study aimed to investigate the effects of biomass on the sintering characteristics of high melting-point anthracite ash during co-firing. The sintering mechanism of ash of the blends of Jincheng coal (JC) and pine sawdust (PS) was analyzed. The sintering of JC coal was tested as a reference to compare the reaction between blended coal and biomass. The results obtained in this study provided a better understanding of the sintering behavior of ash from co-combustion of biomass and coal.

\section{EXPERIMENTAL}

\section{Preparation of Specimens}

An anthracite, JC from Shanxi Province in China, together with PS, were used for this study. The JC and PS were air-dried, and then crushed and sieved to a size fraction of $<100 \mu \mathrm{m}$ and $<0.8 \mathrm{~mm}$, respectively. The JC and the blends of JC with 5\%, 10\%, and $25 \%$ PS addition were prepared. The proximate and ultimate analyses data of JC and PS as well as their ash composition are presented in Table 1.

The ash specimens were prepared in a muffle furnace (MF) (FMJ-08/18; FaceRom, Hefei, China) at three different temperatures, namely, $815{ }^{\circ} \mathrm{C}, 950{ }^{\circ} \mathrm{C}$, and $1100{ }^{\circ} \mathrm{C}$ following the Chinese Standard GB/T 212 (2008). Approximately $0.5 \mathrm{~g}$ of each specimen was placed in a ceramic tray in the MF and then heated to $815^{\circ} \mathrm{C}, 950{ }^{\circ} \mathrm{C}$, and $1100{ }^{\circ} \mathrm{C}$, respectively. After ashing for $2 \mathrm{~h}$, the ash specimen was cooled naturally to room temperature and then collected. 
Table 1. Proximate and Ultimate Analyses and Ash Compositions of $\mathrm{JC}$ and PS

\begin{tabular}{|c|c|c|c|c|c|c|c|c|c|c|c|c|}
\hline & \multicolumn{9}{|c|}{ Proximate Analysis (wt\%) } & \multicolumn{7}{c|}{ Ultimate Analysis (wt\%) } \\
\cline { 2 - 12 } & $\mathrm{M}$ & $\mathrm{V}$ & $\mathrm{A}$ & $\mathrm{FC}$ & $\mathrm{C}$ & $\mathrm{H}$ & $\mathrm{O}$ & $\mathrm{N}$ & \multicolumn{2}{c|}{$\mathrm{S}$} \\
\hline $\mathrm{JC}$ & 2.23 & 8.46 & 20.1 & 69.21 & 65.81 & 3.25 & 6.72 & 0.94 & 0.95 \\
\hline $\mathrm{PS}$ & 10.09 & 76.83 & 0.71 & 12.37 & 49.61 & 5.7 & 44.47 & 0.19 & \multicolumn{2}{c|}{0.01} \\
\hline & \multicolumn{8}{|c|}{ Ash Composition (wt\%) } \\
\cline { 2 - 13 } & $\mathrm{SiO}_{2}$ & $\mathrm{Al}_{2} \mathrm{O}_{3}$ & $\mathrm{Fe}_{2} \mathrm{O}_{3}$ & $\mathrm{CaO}$ & $\mathrm{MgO}$ & $\mathrm{Na}_{2} \mathrm{O}$ & $\mathrm{K}_{2} \mathrm{O}$ & $\mathrm{SO}_{3}$ & $\mathrm{TiO}_{2}$ & $\mathrm{P}_{2} \mathrm{O}_{5}$ & $\mathrm{Cl}$ \\
\hline $\mathrm{JC}$ & 52.5 & 29 & 4.44 & 5.18 & 1.12 & 1.25 & 1.87 & 1.97 & 1.05 & 0.25 & - \\
\hline PS & 12.68 & 2.74 & 2.46 & 35.91 & 12.66 & 2.93 & 21.39 & 3.24 & 0.24 & 5.09 & 0.24 \\
\hline
\end{tabular}

\section{Measurement of Sintering Temperature}

The sintering temperatures of the ash specimens were determined using a pressuredrop sintering temperature measurement technique. The details of this technique have been introduced in the literature (Jing et al. 2011; Li et al. 2016). A compacted ash pellet (8 mm inner diameter and $10 \mathrm{~mm}$ in length) was pressed into the centre of a mullite tube $(8 \mathrm{~mm}$ ID and $100 \mathrm{~mm}$ in length) at $25 \mathrm{MPa}$. The mullite tube was then placed in an electrical heating furnace and heated from ambient temperature at $8^{\circ} \mathrm{C} \mathrm{min}-1$ in air. The air flow rate was passed into the mullite tube at $4 \mathrm{~cm}^{3} \mathrm{~min}^{-1}$ controlled by a mass flow meter. As the temperature increased, the pressure drop across the ash pellet also increased. At the onset of sintering, gas channels would be created in the ash pellet as ash particles sintered, resulting in a rapid decrease in the pressure drop across the ash pellet. The ash sintering temperature was defined as the temperature at which an abrupt change in the rate of pressure drop occurred.

\section{Scanning Electron Microscopy-energy Dispersive Spectroscopy (SEM-EDS) and X-ray Diffraction (XRD) Analysis}

The morphological characteristics and spot composition of the ashes were analysed using a FEI-SIRION-100 (Frequency Electronics, Inc., Hillsboro, OR, USA) field emission SEM analyser aided with an EDAX GENESIS4000 X-ray EDS (EDAX, Philadelphia, Commonwealth of Pennsylvania, USA). The mineralogical characteristics of the ash specimens were obtained using a D/Max-2550PC X-ray diffractometer analyser with copper Ka radiation (Japan Science Corporation, Tokyo, Japan). More details can be checked in Jing et al. (2016).

\section{Thermodynamic Modeling}

The FactSage software package (version 7.3) (Thermfact/CRCT \& GTTTechnologies, Montreal/Aachen, Canada/Germany) (Bale et al. 2016) was used to predict phase transitions of ash specimens. The main oxides $\mathrm{SiO}_{2}, \mathrm{Al}_{2} \mathrm{O}_{3}, \mathrm{CaO}, \mathrm{MgO}, \mathrm{Fe}_{2} \mathrm{O}_{3}, \mathrm{Na}_{2} \mathrm{O}$, $\mathrm{K}_{2} \mathrm{O}, \mathrm{SO}_{3}$, and $\mathrm{Cl}$ of ash specimens of the blends (shown in Table 2) were put into the equilibrium module. Phase formation data for these oxides and their combinations were chosen from the database of FToxid and FACTPS. The calculations were conducted at their sintering temperatures. 
Table 2. Ash Compositions of JC and PS Mixtures

\begin{tabular}{|c|c|c|c|c|c|c|c|c|c|c|c|}
\hline \multirow{2}{*}{ Specimens } & \multicolumn{10}{|c|}{ Ash Composition } \\
\cline { 2 - 13 } & $\mathrm{SiO}_{2}$ & $\mathrm{Al}_{2} \mathrm{O}_{3}$ & $\mathrm{Fe}_{2} \mathrm{O}_{3}$ & $\mathrm{CaO}$ & $\mathrm{MgO}$ & $\mathrm{Na}_{2} \mathrm{O}$ & $\mathrm{K}_{2} \mathrm{O}$ & $\mathrm{SO}_{3}$ & $\mathrm{TiO}_{2}$ & $\mathrm{P}_{2} \mathrm{O}_{5}$ & $\mathrm{Cl}$ \\
\hline $\mathrm{JC}$ & 2.5 & 29 & 4.44 & 5.18 & 1.12 & 1.25 & 1.87 & 1.97 & 1.05 & 0.25 & - \\
\hline $\begin{array}{c}\mathrm{JC}+ \\
5 \% \mathrm{PS}\end{array}$ & 50.51 & 27.69 & 4.34 & 6.72 & 1.70 & 1.33 & 2.85 & 2.03 & 1.01 & 0.49 & 0.01 \\
\hline $\begin{array}{c}\mathrm{JC}+ \\
10 \% P S\end{array}$ & 48.52 & 26.37 & 4.24 & 8.25 & 2.27 & 1.42 & 3.82 & 2.10 & 0.97 & 0.73 & 0.02 \\
\hline $\begin{array}{c}\mathrm{JC}+ \\
25 \% P S\end{array}$ & 42.55 & 22.44 & 3.95 & 12.86 & 4.01 & 1.67 & 6.75 & 2.29 & 0.85 & 1.46 & 0.06 \\
\hline
\end{tabular}

\section{RESULTS AND DISCUSSION}

\section{Effect of Different Ashing Temperatures on the Sintering Temperatures}

Figure 1 shows the trends of the sintering temperatures of the ashes of JC and JC/PS blends at different ashing temperatures. The sintering temperatures of ash of blends decreased with the addition of PS into JC. The trend of reduction was similar when the PS was added at $0,5 \%$, and $10 \%$ at three ashing temperatures, while the extent of reduction increased with the increase of ashing temperatures at 25\% PS addition. This was because adding PS into JC increased the alkali and alkali-earth metals of the blended ash. The violent reactions between alkali and alkali-earth metals and other minerals occurred during the high temperature treatments, and alkali metal minerals can reduce the ash melting point (Zhou et al. 2019), thereby reduced the sintering temperature.

Moreover, the sintering temperatures at lower ashing temperature were lower than those at higher ashing temperature. This may be because more low melting-point minerals appeared during the low-temperature ashing process while there were high-melting-point minerals at high ashing temperature.

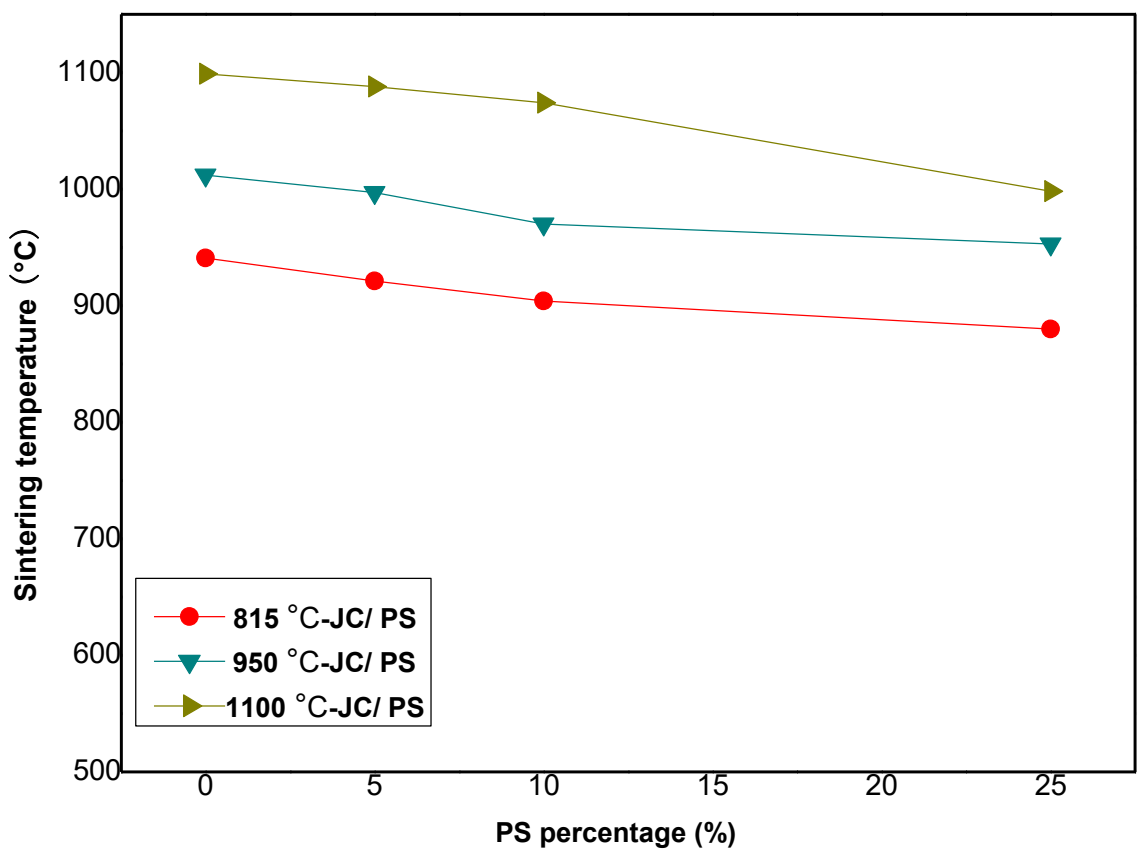

Fig. 1. Sintering temperatures of ashes of JC/PS blends from different ashing temperature 


\section{Ash Morphology by SEM-EDS Analysis}

From the SEM images in Fig. 2, the ash particle of JC appeared dense at the ashing temperature of $815^{\circ} \mathrm{C}$ (Fig. 2(a) and (b)). More small fibrous fragments adhered to the big particles when PS was added into the blends (Fig. 2(c) and (d)). This indicated that the ash of the blends with PS appeared more agglomerated than the raw JC ash. At the same time, compared to the raw JC ash, there were less $\mathrm{Si}, \mathrm{Ca}, \mathrm{Na}$, and $\mathrm{K}$ in the ash of JC with $10 \%$ PS (Fig. 2(e)). The reduction of these elements showed that volatilization of alkalis may occur during the ashing process (Liu et al. 2018) or the melting of $\mathrm{Ca} / \mathrm{K} / \mathrm{Na}$-bearing silicates occurred, and thereby decreasing the sintering temperature of ash of the blends.
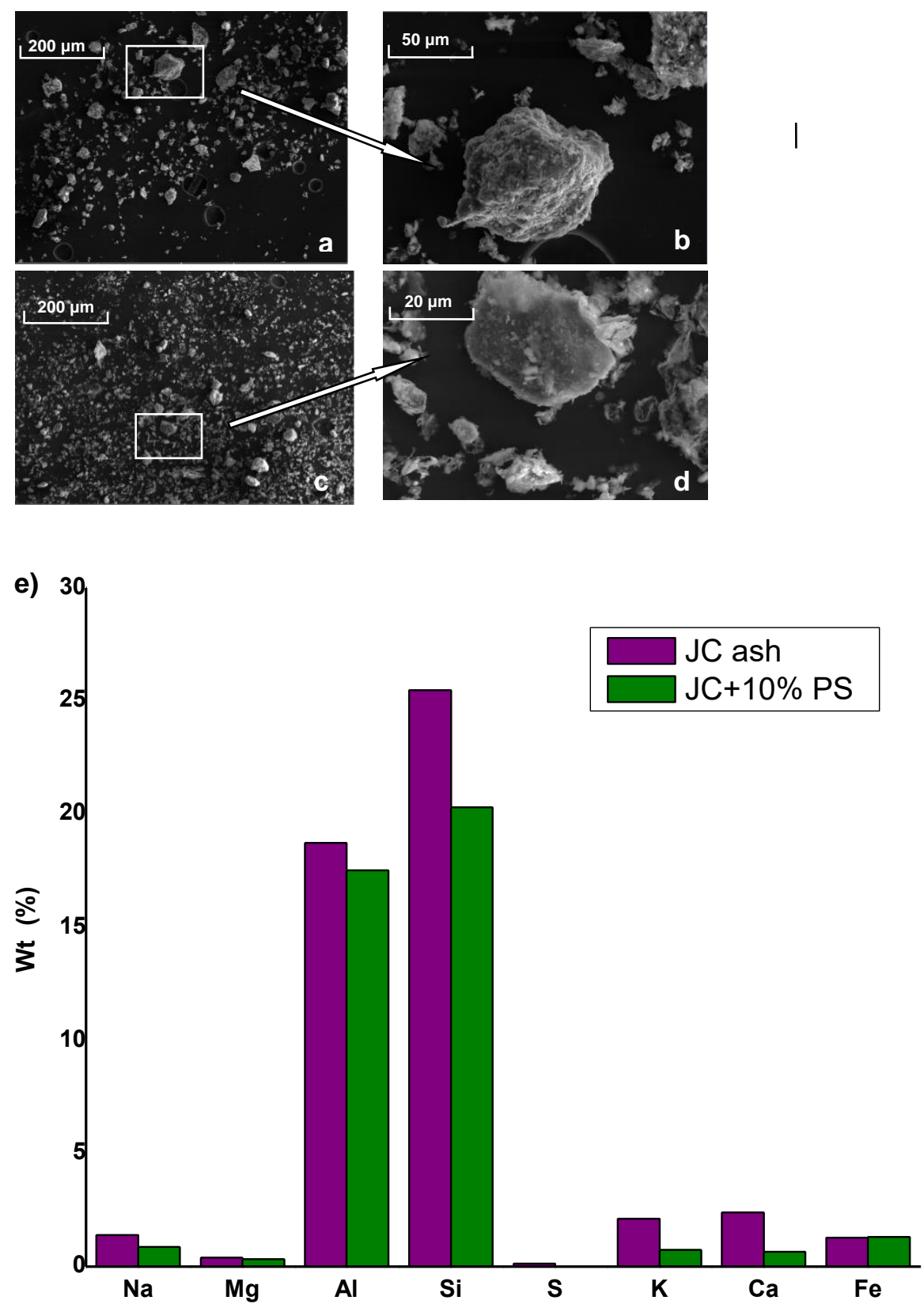

Fig. 2. SEM images and EDS results of the ashes of $\mathrm{JC}$ coal and PS at $815^{\circ} \mathrm{C}$ : a) $\mathrm{JC}$ coal, b) enlarged image of $\mathrm{JC}$ coal, c) $\mathrm{JC}+10 \% \mathrm{PS}$, d) enlarged image of $\mathrm{JC}+10 \% \mathrm{PS}$, and e) EDS results 
Figure 3 shows the SEM patterns of ash of the blends of JC and PS at $950{ }^{\circ} \mathrm{C}$ ashing temperature. It is shown that ash fragmentation was serious at $950{ }^{\circ} \mathrm{C}$ ashing temperature (Fig. 3(a) and (b)). More large particles and more fine particles that adhered to larger particles were detected when 10\% PS was added into JC (Fig. 3(c) and (d)), which indicated that obvious agglomeration among the particles occurred. Compared with the SEM images at $815^{\circ} \mathrm{C}$, there were the agglomerations of more fine particles in the original coal ash at $950^{\circ} \mathrm{C}$. The particles were larger and obvious agglomeration appeared in the mixed ash specimens at $950{ }^{\circ} \mathrm{C}$. It can be seen from the EDS results (Fig. 3(e)) that the contents of Ca and $\mathrm{Fe}$ were obviously higher while $\mathrm{Si}, \mathrm{Na}, \mathrm{Al}, \mathrm{K}$ decreased slightly in $\mathrm{JC}$ ash at $950{ }^{\circ} \mathrm{C}$, compared to that at $815^{\circ} \mathrm{C}$. This indicated that $\mathrm{Na}$ and K-bearing aluminosilicates may be produced in $\mathrm{JC}$ ash at $950{ }^{\circ} \mathrm{C}$. When $10 \%$ PS was added into the $\mathrm{JC}$ ash, $\mathrm{Ca}, \mathrm{Fe}$, and $\mathrm{Si}$ decreased significantly. This may be due to the low temperature co-fusion of $\mathrm{Si}, \mathrm{Ca}$, and Fe-bearing minerals (Zhang et al. 2020), resulting in obvious agglomeration.
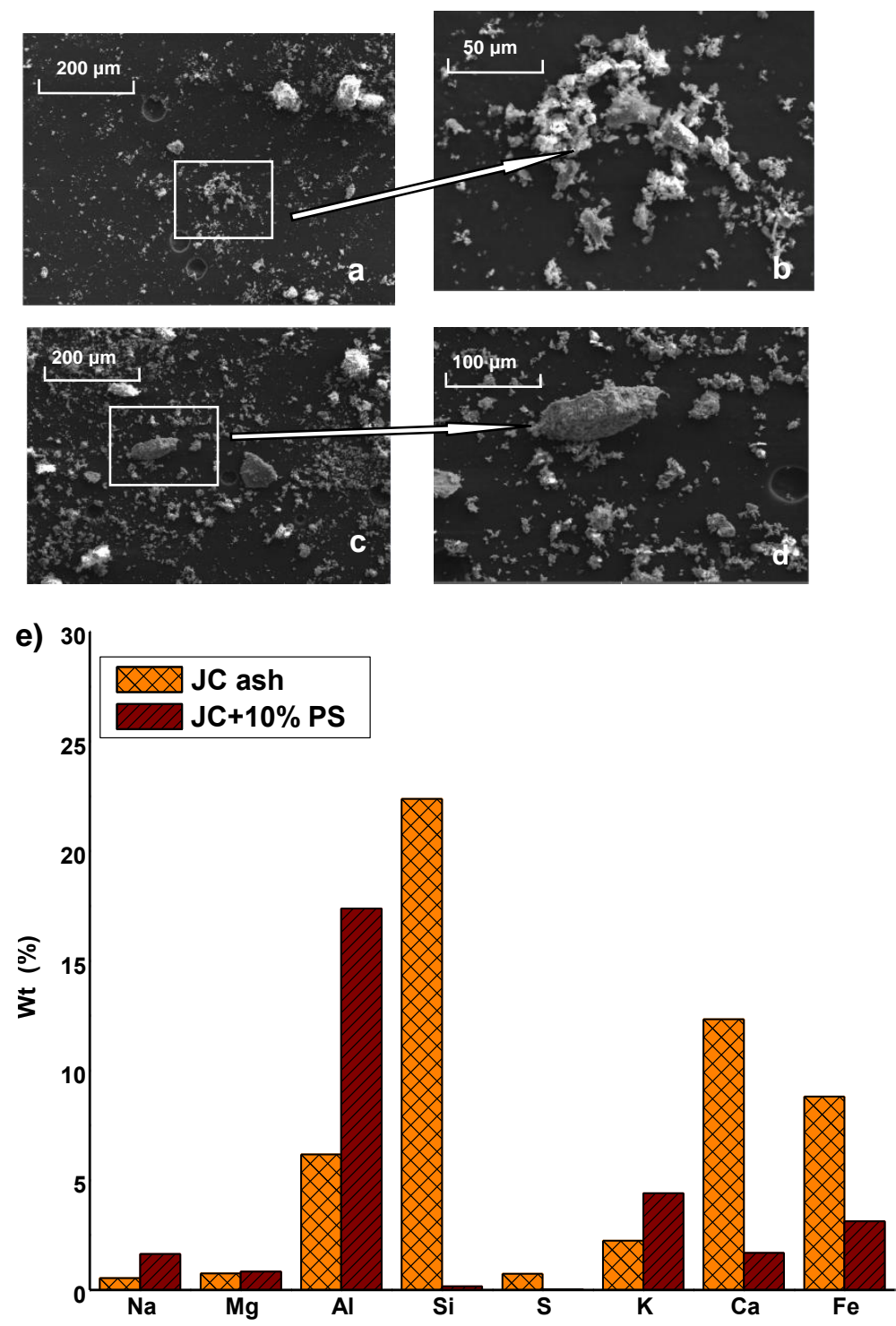

Fig. 3. SEM images and EDS results of the ashes of $\mathrm{JC}$ coal and $\mathrm{PS}$ at $950^{\circ} \mathrm{C}$ : a) $\mathrm{JC}$ coal, b) enlarged image of $\mathrm{JC}$ coal, c) JC+10\%PS, d) enlarged image of $\mathrm{JC}+10 \% \mathrm{PS}$, and e) EDS results 
The SEM images in Fig. 4(a) through (d) show that there were more regular blockshaped particles in the ash specimens at $1100{ }^{\circ} \mathrm{C}$. This indicated that high temperature ashing may lead to a greater extent of reaction in the ash, resulting in melting of ash particles and the generation of new minerals with high melting point. The results of EDS (Fig. 4(e)) showed that more Fe was found in the $\mathrm{JC}$ ash at $1100^{\circ} \mathrm{C}$. Fe-containing mineral has a high melting point, and thereby results in a higher sintering temperature. The content of $\mathrm{Si}$ in the mixed ash increased obviously, and the content of $\mathrm{Ca}$ and $\mathrm{Fe}$ were lower than that in the original JC ash when 10\% PS was added into JC ash. This indicated that there may produce co-fusion of $\mathrm{Ca}$ and Fe-containing minerals in combination with other minerals, and hence the sintering temperature of ash of the blends of JC and $10 \%$ PS decreased, compared to the JC ash.
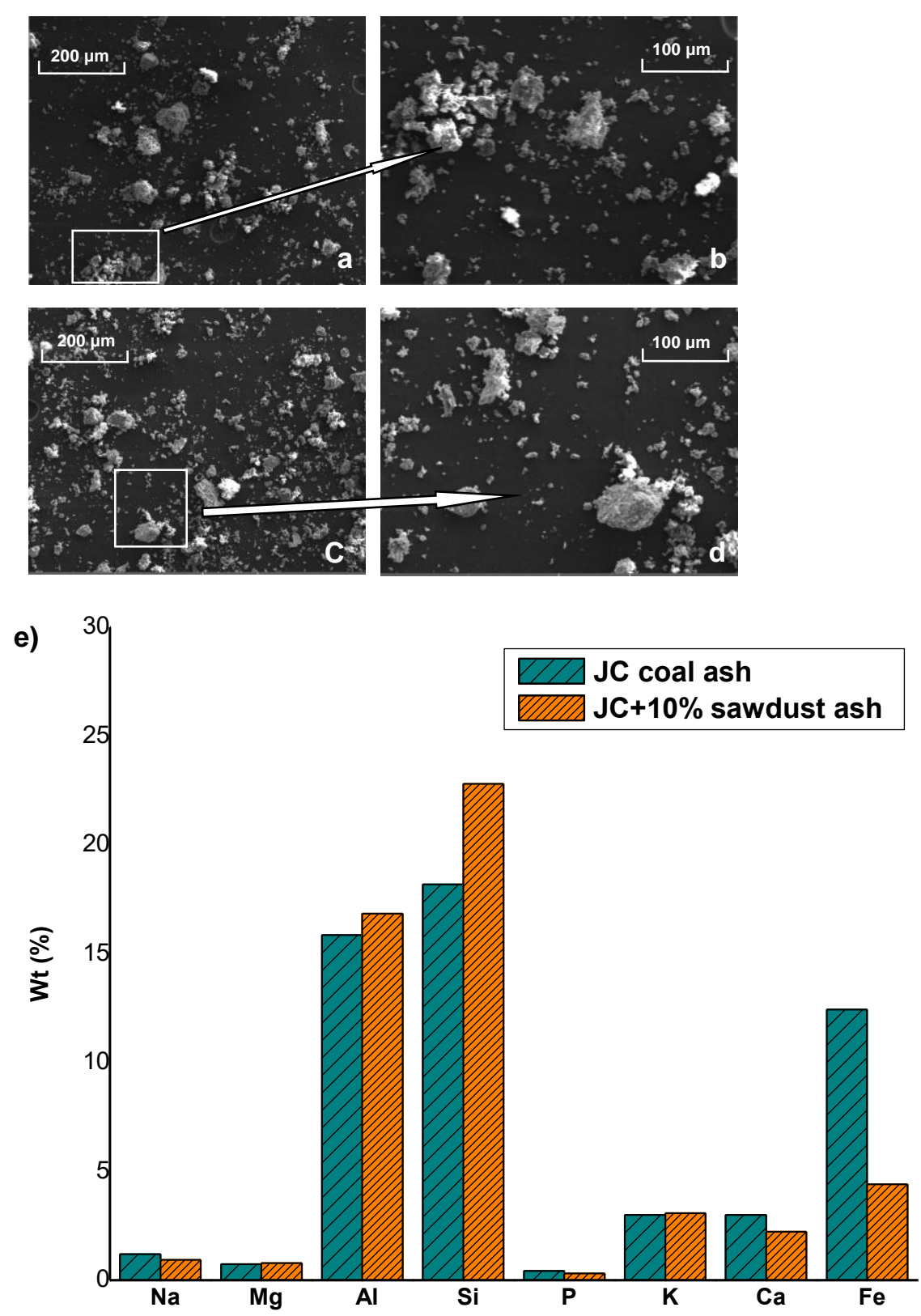

Fig. 4. SEM images and EDS results of the ashes of $\mathrm{JC}$ and PS at $1100^{\circ} \mathrm{C}$ : a) $\mathrm{JC}$ coal, b) enlarged image of $\mathrm{JC}$ coal, c) $\mathrm{JC}+10 \% \mathrm{PS}$, d) enlarged image of $\mathrm{JC}+10 \% \mathrm{PS}$, and e) EDS results 


\section{Ash Mineralogy by XRD}

Figure 5 shows the XRD diffraction patterns of ash of the blends from JC and 10\% PS. The minerals in the mixed ash of JC and $10 \%$ PS are mainly quartz $\left(\mathrm{SiO}_{2}\right)$ and muscovite $\left(\mathrm{KAl}_{2}\left(\mathrm{AlSi}_{3}\right) \mathrm{O}_{10}(\mathrm{OH})_{2}\right)$ at $815{ }^{\circ} \mathrm{C}$, which are the same as those in the original JC ash (Jing et al. 2016). As the ashing temperature was increased to $950{ }^{\circ} \mathrm{C}$, the muscovite disappeared and the diffraction peak of mullite $\left(\mathrm{Al}_{6} \mathrm{Si}_{2} \mathrm{O}_{13}\right)$ and anhydrite appeared both for the original $\mathrm{JC}$ ash and the mixed ash. Moreover, albite $\left(\mathrm{NaAlSi}_{3} \mathrm{O}_{8}\right)$ and sanidine $\left(\mathrm{KAlSi}_{3} \mathrm{O}_{8}\right)$ were detected in the original $\mathrm{JC}$ ash at $950{ }^{\circ} \mathrm{C}$. Compared to the original JC ash, enstatite $\left(\mathrm{MgSiO}_{3}\right)$ appeared in the mixed ash except for mullite and anhydrite $\left(\mathrm{CaSO}_{4}\right)$ at $950{ }^{\circ} \mathrm{C}$. This was because the low temperature $\mathrm{Na} / \mathrm{K}$ - bearing minerals in the raw $\mathrm{JC}$ ash co-fused with other minerals in the PS to produce more Mg-containing minerals. As the temperature rose to $1100^{\circ} \mathrm{C}$, the anhydrite and the enstatite disappeared, and the diffraction peak of the anorthite $\left(\mathrm{CaAl}_{2} \mathrm{Si}_{2} \mathrm{O}_{8}\right)$ appeared. There were the same minerals in the $\mathrm{JC}$ ash and the mixed ash. Additionally, the diffraction peak of mullite was enhanced. This indicated that a part of the product from the decomposition of anhydrite reacted with aluminosilicate in the ash to form a new mineral, anorthite, while the other part of the product reacted to form mullite, which led to the enhancement of the diffraction peak of mullite. Vassileva and Vassilev (2006) reported that the formation of mullite begins at 1073 $\mathrm{K}$. The mullite plays a skeleton supporting role in coal ash and can considerably increase the ash melting point. Therefore, the sintering temperatures were higher at $1100{ }^{\circ} \mathrm{C}$ due to the appearance of high-temperature minerals, which is consistent with the results in Fig. 1.

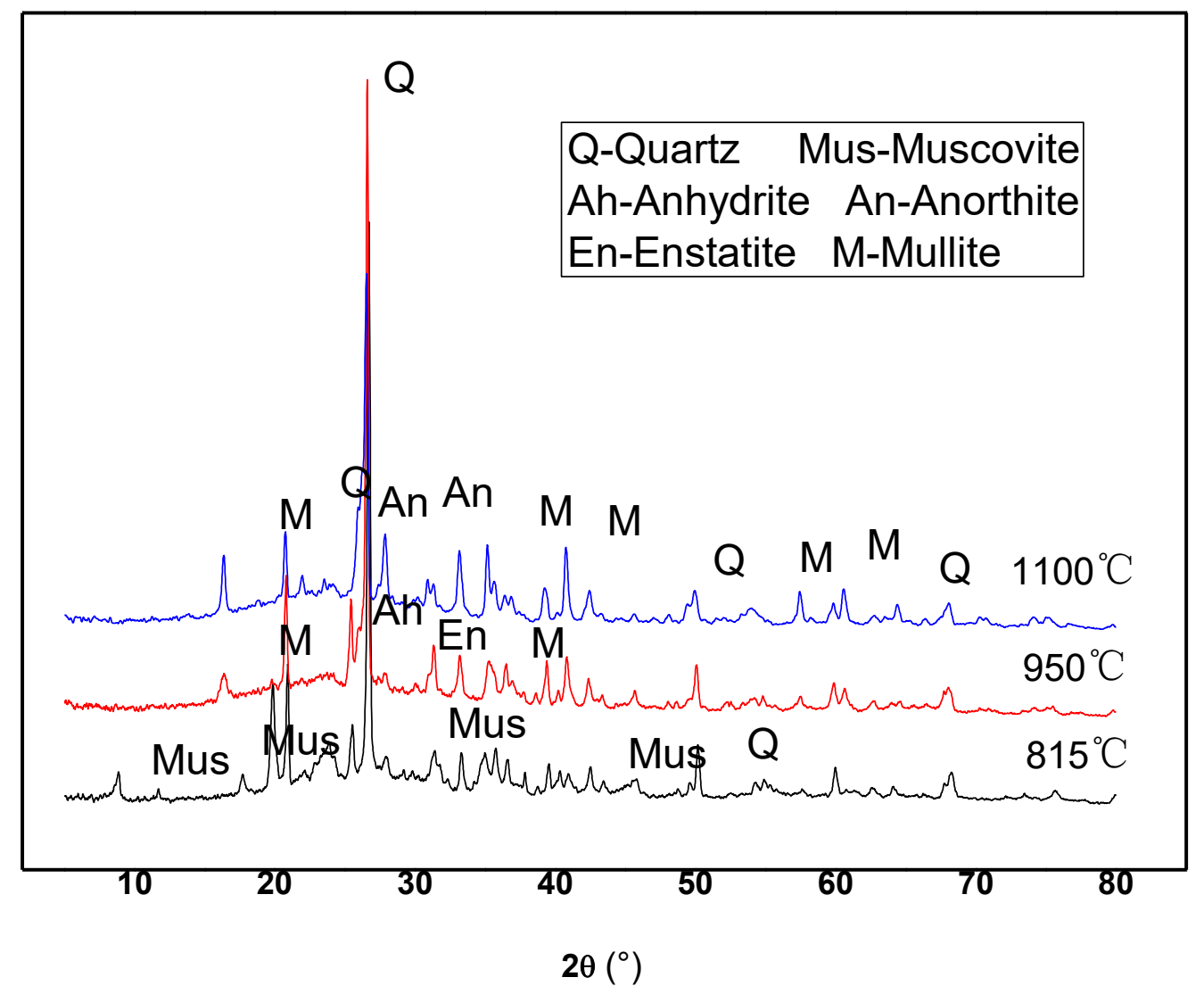

Fig. 5. XRD patterns of the ash of JC with $10 \%$ PS under different ashing temperatures 


\section{FactSage Calculation}

To understand the experimental results better, the FactSage thermodynamical equilibrium module was used to predict proportions of mineral phase at specified temperatures. At $815^{\circ} \mathrm{C}$, as shown in Fig. 6(a), the anorthite $\left(\mathrm{CaAl}_{2} \mathrm{Si}_{2} \mathrm{O}_{8}\right)$ increased with the PS addition and then decreased but the anhydrite $\left(\mathrm{CaSO}_{4}\right)$ appeared at $25 \% \mathrm{PS}$.
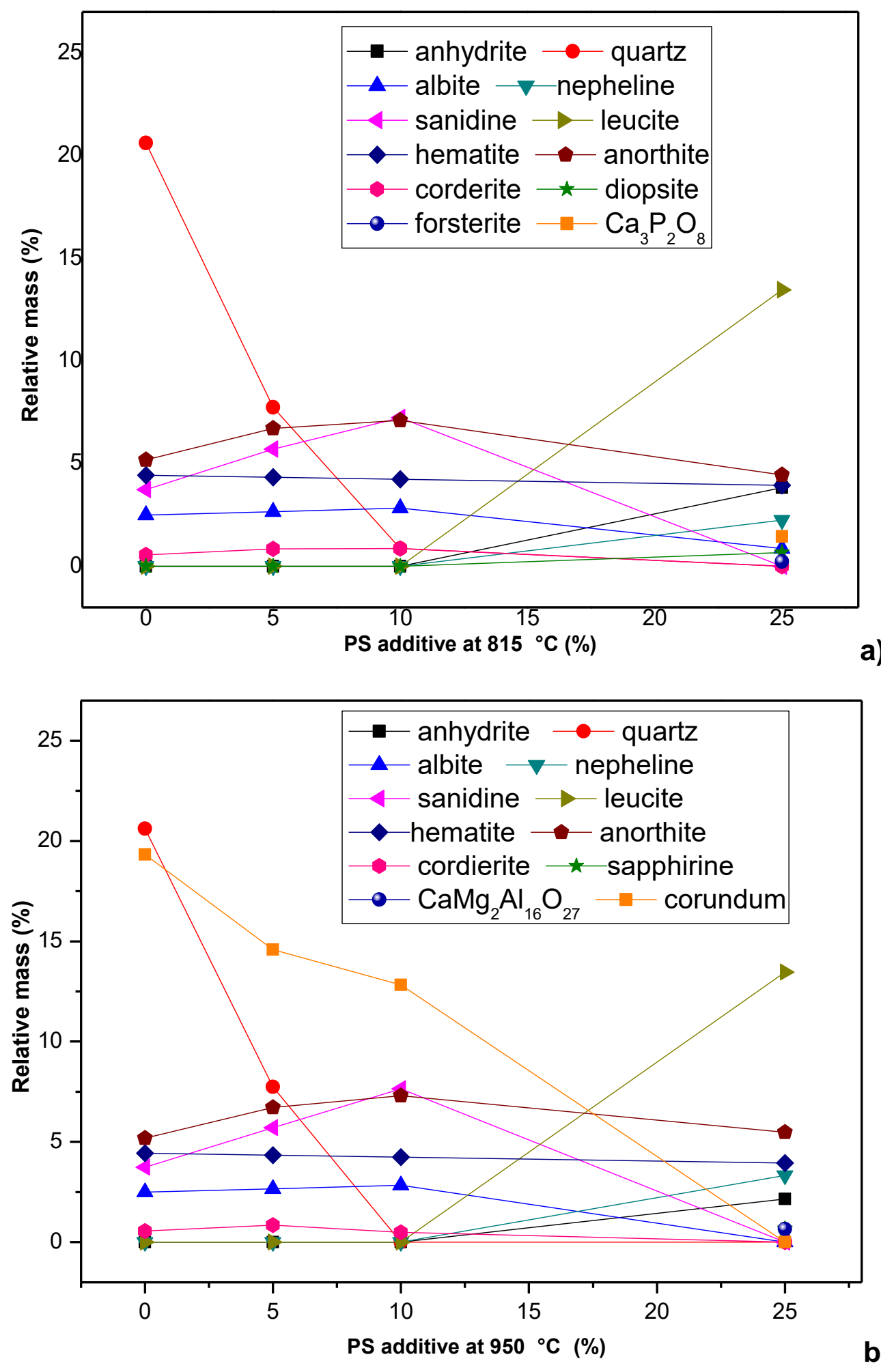


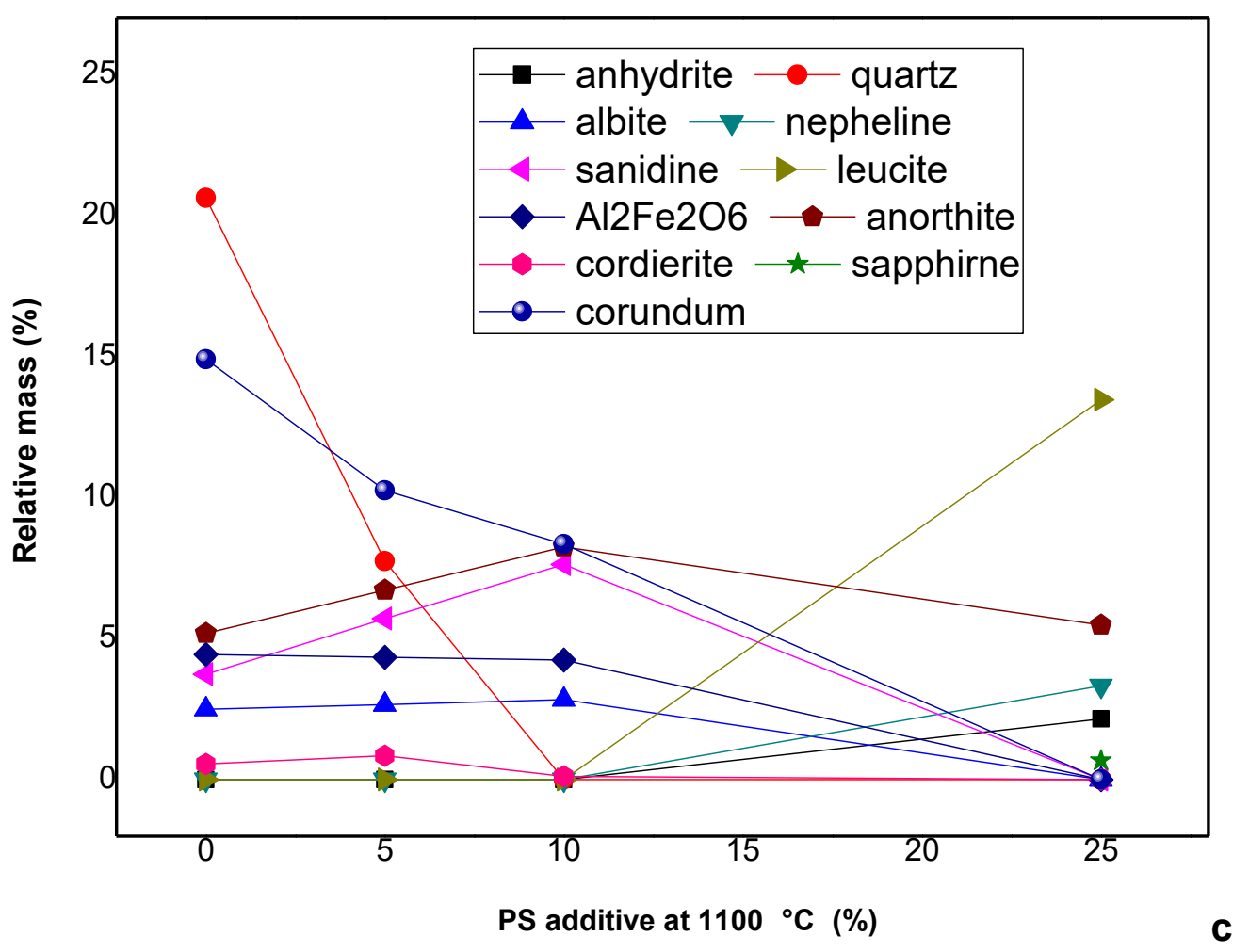

Fig. 6. Effect of PS additive on the minerals with the ashing temperature: a: $815^{\circ} \mathrm{C}$; b: $950{ }^{\circ} \mathrm{C}$; c: $1100{ }^{\circ} \mathrm{C}$

At the same time, albite $\left(\mathrm{NaAlSi}_{3} \mathrm{O}_{8}\right)$ and sanidine $\left(\mathrm{KAlSi}_{3} \mathrm{O}_{8}\right)$ increased with the PS addition and then decreased, and the nepheline $\left(\mathrm{NaAlSiO}_{4}\right)$ and leucite $\left(\mathrm{KAlSi}_{2} \mathrm{O}_{6}\right)$ appeared at $25 \%$ PS. Cordierite $\left(\mathrm{Mg}_{2} \mathrm{Al}_{4} \mathrm{Si}_{5} \mathrm{O}_{18}\right)$ increased and then decreased and the diopsite $\left(\mathrm{CaMgSi}_{2} \mathrm{O}_{6}\right)$ and forsterite $\left(\mathrm{Mg}_{2} \mathrm{SiO}_{4}\right)$ appeared at $25 \%$ PS. Hematite decreased slightly with the increase in the PS additive. Quartz decreased noticeably to disappear at $25 \%$ PS. Figure 6(b) shows that the mineral transformations were similar at $950{ }^{\circ} \mathrm{C}$. Cordierite disappeared at $10 \%$ PS but the sapphirine $\left(\mathrm{Mg}_{4} \mathrm{Al}_{10} \mathrm{Si}_{2} \mathrm{O}_{23}\right)$ and $\mathrm{CaMg}_{2} \mathrm{Al}_{16} \mathrm{O}_{27}$ appeared at $25 \%$ PS. Corundum $\left(\mathrm{Al}_{2} \mathrm{O}_{3}\right)$ changed noticeably. Due to high contents of $\mathrm{K}$, $\mathrm{Ca}$, and $\mathrm{Mg}$ in PS, the production of leucite, sapphirine, and $\mathrm{CaMg}_{2} \mathrm{Al}_{16} \mathrm{O}_{27}$ increased and then resulted in the decrease of $\mathrm{Al}_{2} \mathrm{O}_{3}$. The migration of $\mathrm{K}, \mathrm{Ca}, \mathrm{Mg}, \mathrm{Si}$, and $\mathrm{Al}$ were obvious. The migration of $\mathrm{Na}$ and $\mathrm{Fe}$ were not obvious.

Figure 6(c) indicates that the mineral transformations at $1100{ }^{\circ} \mathrm{C}$ were still similar with those at $815^{\circ} \mathrm{C}$ and $950^{\circ} \mathrm{C}$. Only the hematite changed into $\mathrm{Al}_{2} \mathrm{Fe}_{2} \mathrm{O}_{6}$. The content of corundum was different with that at $950{ }^{\circ} \mathrm{C}$. At $1100{ }^{\circ} \mathrm{C}$, the hematite combined with $\mathrm{Al}_{2} \mathrm{O}_{3}$ to produce $\mathrm{Al}_{2} \mathrm{Fe}_{2} \mathrm{O}_{6}$. Hence, the content of corundum was less than that at $950{ }^{\circ} \mathrm{C}$. At $25 \%$ PS, $\mathrm{Al}_{2} \mathrm{Fe}_{2} \mathrm{O}_{6}$ decreased. It could be deduced that the element of $\mathrm{Fe}$ is wrapped or melted at $1100{ }^{\circ} \mathrm{C}$. Calcium and $\mathrm{Fe}$ increased and then decreased, while $\mathrm{Mg}, \mathrm{Na}$, and $\mathrm{K}$ increased.

The cations $\left(\mathrm{Na}^{+}, \mathrm{Ca}^{2+}\right.$, etc.) of fluxing agents are both electron acceptors. They can easily enter into the mullite lattice through high-activity oxygen atoms, forcing the transformation of mullite structures (Li et al. 2009).

Subsequently, the alkali and alkali earth metal species mainly changed into solid particles existed in the forms of aluminosilicates (e.g., $\mathrm{NaAlSi}_{3} \mathrm{O}_{8}, \mathrm{KAlSi}_{3} \mathrm{O}_{8}$, and $\left.\mathrm{CaAl}_{2} \mathrm{Si}_{2} \mathrm{O}_{8}\right)$ and silicates $\left(\mathrm{Mg}_{2} \mathrm{SiO}_{4}\right.$ and $\left.\mathrm{CaMgSi}_{2} \mathrm{O}_{6}\right)$. 
Meanwhile, the elements of alkaline earth metals and Fe were transferred into some higher MP silicates and aluminate (e.g., $\mathrm{Mg}_{2} \mathrm{SiO}_{4}$ and $\mathrm{Al}_{2} \mathrm{Fe}_{2} \mathrm{O}_{6}$ ). The calcium, magnesium, and potassium played a vital role during the sintering of high blend ratio of PS.

\section{CONCLUSIONS}

In this work, the sintering temperatures of JC and JC/PS blends at different ashing temperatures were measured using a pressure-drop sintering device, and the microscopy and mineralogy of ashes were studied by SEM-EDS and XRD analysis. The conclusions from the study are as follows:

1. With the addition of PS into JC, the sintering temperatures of mixed ashes decreased. The sintering temperatures of mixed ashes under the high ashing temperature were lower than those of blended ashes when the ashing temperature was lower.

2. The SEM analysis showed that fine, irregular, and fibrous texture can be detected in the ash specimens from the lower ashing temperature. Regular block-shape particles were present in the ash specimens under the higher ashing temperature. The EDS results showed that more $\mathrm{Ca}$ and $\mathrm{Fe}$ appeared with the increase in the ashing temperature and more $\mathrm{K}$ and $\mathrm{Na}$ appeared and $\mathrm{Ca}$ and $\mathrm{Fe}$ decreased with the addition of PS. This indicated the the $\mathrm{Ca} / \mathrm{Fe}$-containing minerals appeared with increased ashing temperature while more $\mathrm{Na} / \mathrm{K}$-containing minerals dominated with the increase in the addition of PS into JC.

3. The XRD analysis revealed that low-temperature minerals may be melted or co-fused and new minerals were formed when $10 \%$ PS was added into the coal (e.g., $\mathrm{NaAlSi}_{3} \mathrm{O}_{8}$ and $\mathrm{KAlSi}_{3} \mathrm{O}_{8}$ transformed into $\mathrm{MgSiO}_{3}$ ), while the high-temperature minerals (e.g., mullite and anorthite) formed with the increase in ashing temperature. The FactSage calculation showed that the alkali and alkali earth metal species mainly changed into solid particles existing in the forms of aluminosilicates (e.g., $\mathrm{NaAlSi}_{3} \mathrm{O}_{8}, \mathrm{KAlSi}_{3} \mathrm{O}_{8}$, and $\left.\mathrm{CaAl}_{2} \mathrm{Si}_{2} \mathrm{O}_{8}\right)$ and silicates $\left(\mathrm{Mg}_{2} \mathrm{SiO}_{4}\right.$ and $\left.\mathrm{CaMgSi}_{2} \mathrm{O}_{6}\right)$. The elements of alkaline earth and $\mathrm{Fe}$ were transferred into some higher MP silicates and aluminate (e.g., $\mathrm{Mg}_{2} \mathrm{SiO}_{4}$ and $\mathrm{Al}_{2} \mathrm{Fe}_{2} \mathrm{O}_{6}$ ). The migration of $\mathrm{K}, \mathrm{Ca}, \mathrm{Mg}, \mathrm{Si}$, and $\mathrm{Al}$ were obvious. The calcium, magnesium, and potassium played a vital role during the sintering of the blends with PS.

\section{ACKNOWLEDGEMENTS}

This work was financially supported by Zhejiang Province Natural Science Foundation Project of China (No. LGG18E060004). The authors thank the support of National Natural Science Foundation Project of China (51506042).

\section{REFERENCES CITED}

Bale, C. W., Bélisle, E., Chartrand, P., Decterov, S. A., Eriksson, G., Gheribi, A. E., Hack, K., Jung, I.-H., Kang, Y.-B., Melaçon, J., et al. (2016). "Reprint of: FactSage

Jing et al. (2020). "Sintering of ash from combustion," BioResources 15(4), 9324-9336. 
thermochemical software and databases, 2010-2016," Calphad 55(Part 1), 35-53. DOI: 10.1016/j.calphad.2016.07.004

Chen, M. Q., Yu, D., and Wei, Y. H. (2015). "Evaluation on ash fusion behavior of eucalyptus bark/lignite blends," Powder Technology 286, 39-47. DOI: 10.1016/j.powtec.2015.07.043

GB/T 212 (2008). "Methods of industrial analysis of coal," Standardization Administration of China, Beijing, China.

Jing, N. J., Wang, Q. H., Luo, Z., and Cen, K. F. (2011). "Effect of different reaction atmospheres on the sintering temperature of Jincheng coal ash under pressurized conditions," Fuel 90(8), 2645-2651. DOI: 10.1016/j.fuel.2011.04.013

Jing, N. J., Zhu, M. M., Shen, G. Q., Wang, Q. H., and Zhang, D. K. (2016). "Effect of ash preparation method on the sintering characteristics of ashes from combustion of coal and biomass blends," Fuel 186, 830-837. DOI: 10.1016/j.fuel.2016.09.041

Kułazynski, M., Jabłonski, S., Kaczmarczyk, J., Swiatek, Ł., Pstrowska, K., and Łukaszewicz, M. (2018). "Technological aspects of sunflower biomass and brown coal co-firing," Journal of the Energy Institute 91(5), 668-675. DOI: 10.1016/j.joei.2017.06.003

Li, J., Du, M. F., Zhang, Z. X., Guan, R. Q., Chen, Y. S., and Liu, T. Y. (2009) "Selection of fluxing agent for coal ash and investigation of fusion mechanism: a first-principles study, "Energy \& Fuels 23, 704-709. DOI: 10.1021/ef800784k

Li, J. B., Zhu, M. M., Zhang, Z. Z., Zhang, K., Shen, G. Q., and Zhang, D. K. (2016). "Characterisation of ash deposits on a probe at different temperatures during combustion of a Zhundong lignite in a drop tube furnace," Fuel Processing Technology 144, 155-163. DOI: 10.1016/j.fuproc.2015.12.024

Li, J. B., Zhu, M. M., Zhang, Z. Z., and Zhang, K. (2016). "A new criterion for determination of coal ash sintering temperature using the pressure-drop technique and the effect of ash mineralogy and geochemistry," Fuel 179, 71-78. DOI: 10.1016/j.fuel.2016.03.078

Liu, Y. Z., He, Y., Wang, Z. H., Xia, J., Wan, K. D., Whiddon, R., and Cen, K. (2018). "Characteristics of alkali species release from a burning coal/biomass blend," Applied Energy 215, 523-531. DOI: 10.1016/j.apenergy.2018.02.015

Lu, G. J., Zhang, K., and Cheng, F. Q. (2018). "The fusion characteristics of ashes from anthracite and biomass blends," Journal of the Energy Institute 91(5), 797-804. DOI: 10.1016/j.joei.2017.05.001

Priyanto, D. E., Ueno, S., Sato, N., Kasai, H., Tanoue, T., and Fukushima, H. (2016). "Ash transformation by co-firing of coal with high ratios of woody biomass and effect on slagging propensity," Fuel 174, 172-179. DOI: 10.1016/j.fuel.2016.01.072

Rizvi, T., Xing, P., Pourkashanian, M., Darvell, L. I., Jones, J. M., and Nimmo, W. (2015). "Prediction of biomass ash fusion behaviour by the use of detailed characterisation methods coupled with thermodynamic analysis," Fuel 141, 275-284. DOI: 10.1016/j.fuel.2014.10.021

Sajdak, M., Kmieć, M., Micek, B., and Hrabak, J. (2019). "Determination of the optimal ratio of coal to biomass in the co-firing process: Feed mixture properties," International Journal of Environmental Science and Technology 16(7), 2989-3000. DOI: 10.1007/s13762-018-1864-y.

Sami, M., Annamalai, K., and Wooldridge, M. (2001). "Co-firing of coal and biomass fuel blends," Progress in Energy and Combustion Science 27(2), 171-214. DOI: 10.1016/S0360-1285(00)00020-4 
Selvakumaran, P., Lawerence, A., and Bakthavatsalam, A. K. (2014). "Effect of additives on sintering of lignites during CFB combustion," Applied Thermal Engineering 67, 480-488. DOI: 10.1016/j.applthermaleng.2014.03.031

Teixeira, P., Lopes, H., Gulyurtlu, I., Lapa, N., and Abelha, P. (2012). "Evaluation of slagging and fouling tendency during biomass co-firing with coal in a fluidized bed," Biomass and Bioenergy 39, 192-203. DOI: 10.1007/s13762-018-1864-y

Vassileva, C. G., and Vassilev, S. V. (2006). "Behaviour of inorganic matter during heating of Bulgarian coals. 2. Subbituminous and bituminous coals," Fuel Processing Technology 87(12), 1095-1116. DOI: 10.1016/j.fuproc.2006.08.006

Vuthaluru, H. B., Doshi, V., Korbee, R., Kiel, J. H. A., Shah, K., and Moghtager, B. (2015). "Co-firing of coal and biomass: Development of a conceptual model for ash formation prediction," Fuel 139, 594-605. DOI: 10.1016/j.fuel.2014.09.028

Wei, J., Guo, Q., and Gong, Y. (2017). "Synergistic effect on co-gasification reactivity of biomass-petroleum coke blended char," Bioresource Technology 234, 33-39.

DOI: 10.1016/j.biortech.2017.03.010

Xing, P., Darvell, L. I., Jones, J. M., Ma, L., Pourkashanian, M., Szuhanszki, J., and Williams, A. (2019). "The use of equilibrium thermodynamic models for the prediction of inorganic phase changes in the co-firing of wheat straw with El Cerrejon coal," Journal of the Energy Institute 92(3), 813-823. DOI:

10.1016/j.joei.2018.02.003

Xiong, Q. A., Li, J. Z., Guo, S., Li, G., Zhao, J. T., and Fang, Y. T. (2018). “Ash fusion characteristics during co-gasification of biomass and petroleum coke," Bioresource Technology 257, 1-6. DOI: 10.1016/j.biortech.2018.02.037

Zhang, J. K., and Zhou, H. (2019). "Investigation of the slagging characteristics during co-combustion of Shenhua coal and corn stalk: Effect of deposition surface," Fuel 256, Article ID 115939. DOI: 10.1016/j.fuel.2019.115939

Zhang, H., Wu, S. Z., Yang, Y. F., Cheng, J. L., Lun, F., and Wang, Q. S. (2020). "Mineral distribution in pulverized blended Zhundong coal and its influence on ash deposition propensity in a real modern boiler situation," ACS Omega 5(9), 43864394. DOI: 10.1021/acsomega.9b02928

Zhou, H., and Ma, W. C. (2017). "An experimental study on the effects of adding biomass ashes on ash sintering behavior of Zhundong coal," Applied Thermal Engineering 126, 689-701. DOI: 10.1016/j.applthermaleng.2017.07.199

Zhou, H., Ma, W. C., Zhang, J. K., Xu, Y., and Zhao, M. H. (2018). "Ash deposition behavior under coal and wood co-firing conditions in a $300 \mathrm{~kW}$ downfired furnace," Journal of the Energy Institute 91(5), 743-755. DOI: 10.1016/j.joei.2017.05.007

Zhou, H., Luo, Z. H., Liu, D., and Ma, W. C. (2019). "Effect of biomass ashes on sintering characteristics of high/low melting bituminous coal ash," Fuel Processing Technology 189, 62-73. DOI: 10.1016/j.fuproc.2019.01.017

Zhu, Y. M., Zhang, H., Niu, Y. Q., Xu, H. T., Zhang, X., Hui, S. E., and Tan, H. Z. (2018). "Experiment study on ash fusion characteristics of cofiring straw and sawdust," Energy \& Fuels 32(1), 525-531. DOI: 10.1021/acs.energyfuels.7b03104

Article submitted: June 21, 2020; Peer review completed: September 19, 2020; Revised version received and accepted: October 17, 2020; Published: October 23, 2020.

DOI: 10.15376/biores.15.4.9324-9336 